\title{
Evaluation of The Implementation of The Alternaive $X$ Tourism Strategy As The Implementation of The Strategic Plan For The Tourism Service of The Province of Jatim 2016 -2021
}

\author{
Tri Cicik Wijaya ${ }^{1}$ \\ ${ }^{1}$ Universitas Muhammadiyah Gresik Indonesia \\ tricicik@umg.ac.id
}

\begin{abstract}
ABSTRAK
Hanya ada 1 teknik analisis pada tahap keputusan dalam penyusunan strategi untuk menentukan daya tarik relative dan tidakan alternative yang layak. Teknik tersebut adalah Quantitive Strategic Planning Matrix (QSPM) yang membentuk tahap 3 strategi formulasi. QSPM merupakan alat yang memungkinkan penyusun strategi untuk mengevaluasi faktor kunci internal. Secara konseptual, QSPM menentukan daya tarik relative dari berbagai strategi dari sejauh mana faktor kesuksesan kunci internal dan eksternal dimanfaatkan atau ditingkatkan. Penelitian ini dimulai dengan menganalisa pada Desa Kebon Agung Kecamatan Ujung Pangkah dan rencana pengembangan UKM, dilanjutkan dengan mengimplementasikan model selanjutnya emplementasi model Strategi tersebut dapat direkonstruksi ulang yang disesuaikan dengan kondisi u Pengembangan. Hanya ada 1 teknik analisis pada tahap keputusan dalam penyusunan strategi untuk menentukan daya tarik relative dan tidakan alternative yang layak. Teknik tersebut adalah Quantitive Strategic Planning Matrix (QSPM) yang membentuk tahap 3 strategi formulasi. QSPM merupakan alat yang memungkinkan penyusun strategi untuk mengevaluasi faktor kunci internal. Secara konseptual, QSPM menentukan daya tarik relative dari berbagai strategi dari sejauh mana faktor kesuksesan kunci internal dan eksternal dimanfaatkan atau ditingkatkan . Terkait strategi SDM, progam pengembangan sdm untuk kinerja .
\end{abstract}

Kata Kunci : Quantitive Strategic Planning Matrix, SDM

\begin{abstract}
There is only one analytical technique at the decision stage in strategy formulation to determine the relative attractiveness and appropriate alternative actions. The technique is the Quantitive Strategic Planning Matrix (QSPM) which forms stage 3 of the formulation strategy. QSPM is a tool that enables strategists to evaluate internal key factors. Conceptually, the QSPM determines the relative attractiveness of various strategies from the extent to which key internal and external success factors are utilized or enhanced. This research begins by analyzing the Kebon Agung village, Ujung Pangkah sub-district and the SME development plan, followed by implementing the next model, the implementation of the strategy model can be reconstructed according to the conditions of development. There is only one analytical technique at the decision stage in strategy formulation to determine the relative attractiveness and appropriate alternative actions. The technique is the Quantitive Strategic Planning Matrix (QSPM) which forms stage 3 of the formulation strategy. QSPM is a tool that enables strategists to evaluate internal key factors. Conceptually, QSPM determines the relative attractiveness of various strategies from the extent to which key internal and external success factors are utilized or enhanced. Regarding HR strategy
\end{abstract}

Keywords: Quantitive Strategic Planning Matrix, Human Resources

\section{INTRODUCTION}

Kebonagung Village is one of the villages included in the Ujungpangkah sub-district, Gresik Regency which was formerly located east of the highway. Previously, Kebonagung Village consisted of 3 small hamlets named Bondalem, Murtowo, Bonsari which were only inhabited by a few dozen families. Because in the early 50s there was an outbreak of infectious diseases so that many people died.

According to the history told by village elders at that time, in 1950 the 3 hamlets were moved to the west, then changed its name to Kebonagung Village until now. The condition of the population at that time was very alarming because of the lack of health care, as well as the 
number of disease outbreaks, people never reaped the harvest. Coupled with the management system which is still traditional by relying on the weather. Efforts have been made to overcome disease outbreaks, such as hiring a team of wild boar and monkey hunters and working together to eradicate monkeys and pigs. Since then, Kebonagung Village has become a village that has moved from adversity and over time, Kebonagung Village has become a fertile and prosperous village. East Java, especially Kebon Agung, is a big city where tourism deposits need to be developed. currently still not optimal. For that it needs to be optimized

According to Arthur, Gamble, Peteraf, Margaret and Strickland III (2016: 1:32) strategy involves four types of strategic actions and initiatives at different levels, namely Corporate Strategy, Business Strategy, Functional Strategy and Operations Strategy. A business (level) strategy is an integrated and coordinated set of commitments and actions that companies use to gain a competitive advantage by leveraging core competencies in a particular product market (Hitt, Ireland and Hoskisson, 2011; Johnson, Scholes, and Whittington, 2005). Business strategy shows the choices that competing firms make in individual markets/products. Long-term performance is related to the company's diversified strategy using one of the corporatelevel strategies as well as separate business strategies for each competing product market area. The company's strategic choice to compete is shown by the business strategy to respond to many external and internal pressures and influences and must adapt reality into actions that have environmental motives, capabilities based and expectations. The main elements forming a business strategy are the basic issues of competition, how to achieve competitive advantage and detailed development directions such as new products/markets and consideration of methods such as acquisitions or alliances (Johnson, et al, 2005). The company's strategic choice to compete is shown by the business strategy to respond to many external and internal pressures and influences and must adapt reality into actions that have environmental motives, capabilities based and expectations. The main elements forming a business strategy are the basic issues of competition, how to achieve competitive advantage and detailed development directions such as new products/markets and consideration of methods such as acquisitions or alliances (Johnson, et al, 2005). The company's strategic choice to compete is shown by the business strategy to respond to many external and internal pressures and influences and must adapt reality into actions that have environmental motives, capabilities based and expectations. The main elements forming a business strategy are the basic issues of competition, how to achieve competitive advantage and detailed development directions such as new products/markets and consideration of methods such as acquisitions or alliances (Johnson, et al, 2005).

The type or choice of business strategy broadly according to experts' opinions refers to Porter's (1980) generic competitive strategy approach which consists of cost leadership, differentiation and focus that results in consistency of product, market, and special competence choices as well as mutually reinforcing choices (Hill and Jones, 2009) as well as a combination or integration of the two or three strategies in an integrated manner. Another type of business strategy refers to the typology of Miles and Snow (1978) which includes Prospector, Defender, Analyzer and Reactor. There are three main criteria for the success of the choice of strategy, namely: suitability with regard to strategies to cope with circumstances in organizations operating in strategic positions,

Tourism is one of the economic resources of a country or region, because it can increase foreign exchange for the country and the region. For this reason, the central government fully supports regional governments in an effort to advance the tourism sector in various regions in 
Indonesia. One thing that is done to advance the tourism sector is to manage the environment around tourism sites, build facilities to improve the comfort of tourists, maintain the environment and facilities that have been built, and pay attention to other supporting factors such as access to tourist areas and existing infrastructure in the area. the area.

Tourism development has three functions, namely: to promote the economy, maintain the nation's personality and preserve the function and quality of the environment, as well as foster a sense of love for the homeland and nation. To carry out these three functions, it is necessary to develop tourism objects and tourist attractions, improve and develop promotion and marketing, as well as improve tourism education and training (Joyosuharto, 1995:46).

So far, the tourism sector has indeed become one of the mainstays of the East Java regional economy and is the third contributor to Regional Original Income (PAD) after Motor Vehicle Taxes and Land and Building Taxes which lasted until security disturbances such as the Bali bombing exploded, the SARS epidemic, earthquake and natural disaster eruption of Mount Agung which resulted in the decline of Bali tourism. To restore the economic condition of the Bali region, the Bali Regional Government with the support of the Central Government seeks to restore the image of the Bali region in the eyes of the international community, especially in the fields of security and development and management of diversified tourism objects. One of the potential tourist attractions to be marketed to tourists, both foreign tourists and domestic tourists, is agro-tourism. Agricultural tourism is an area, commodity or agricultural activity in a broad sense, which is the object of tourist visits in an effort to obtain physical and or spiritual pleasure, and at the same time it is also possible for tourists to purchase products from the agricultural area visited or farmers provide various packages of attractions that related to agriculture, which in turn can increase the income of farmers, both individually and in groups.

In addition, there are 3 indicators for the success of the DisParDa Strategic Plan program, which include: an increase in the average length of stay of tourists, an increase in the number of tourist visits, and an increase in the average expenditure of tourists. These 3 benchmark indicators are expected to be achieved through 4 pillars of the ministry, namely: tourism destination development, tourism institutional development, tourism marketing development, and tourism industry development. One way to fulfill these indicators is through the development of alternative tourism in agrotourism villages.

Based on the potential of East Java in particular, it is reasonable to develop agrotourism which combines culture and nature, namely tourism management activities that emphasize tourism that does not damage the environment but keeps the environment sustainable and harmonious. In contrast to agricultural activities in other places. In Kebon Agung, agricultural management is a unique thing that can be seen, felt, and lived. This cultural procession can vary greatly from one area to another in Kebon Agung, because of the variety of life and life in various areas of agricultural cultivation in Kebon Agung. It is not an exaggeration that this potential can be packaged more specifically and more attractively and will be a future tourism potential for Kebon Agung Village, Ujung Pangkah District. Thus, through agro-tourism is not only a business business in the field of services that sells services for the fulfillment of consumers of beautiful scenery and fresh air, but can also act as a medium for promoting agricultural products, becoming a media for public education, providing a signal for opportunities to develop diversification of agribusiness and This means it can also become a new growth area for the region. In addition, agro-tourism can also be a source of new regional growth in the agricultural sector and the national economy. provide a signal for the 
opportunity to develop diversification of agribusiness products and also mean it can become a new growth area for the region. In addition, agro-tourism can also be a source of new regional growth in the agricultural sector and the national economy. provide a signal for the opportunity to develop diversification of agribusiness products and also mean it can become a new growth area for the region In addition, agro-tourism can also be a source of new regional growth in the agricultural sector and the national economy.

In reality, the development of the tourism sector in Kebon Agung still seems to show inequalities that need serious attention by the government, the private sector and the community. The inequality, among others, the development of object products and tourism attractiveness is less evenly distributed and less in favor of community empowerment, especially the farming community. There is an impression that the tourism sector is only owned and enjoyed by a certain group of people. Therefore, in the context of equitable distribution and fairness of tourism development, it is necessary to diversify products, objects and tourism activities in the form of agro-tourism in order to take advantage of the potential that exists in farming communities. The development of agro-tourism in Kebon Agung is an effort to diversify the types of tourism objects and at the same time spread tourism to remote areas of the countryside where agricultural areas are located in a broad sense. Kebon Agung has the potential for agro-tourism, for example agrotourism in citrus plantations, durian, vegetables, etc. Some agro-tourism areas have developed into tourist areas because they have beautiful panoramas and good accessibility.

However, until now the effectiveness of the strategy owned by the village of Kebon Agung, Ujung Pangkah sub-district is unknown, while to innovate a product several strategies are needed. For this purpose, it is necessary to conduct a scientific study to develop strategies and programs for the development of the agrotourism area

\section{LITERATURE REVIEW}

Definition of Strategy

The word strategy is derived from the Greek word "strategos" which means military commander in the Athenian democracy. At first this word was only used for military purposes, but it continued to grow so that the word strategic was used in management.

Strategy is an overall approach related to the implementation of ideas, planning, and execution of an activity within a certain period of time. According to Henry Mintzberg (1998), a business and management expert, that the notion of strategy is divided into 5 definitions, namely strategy as a plan, strategy as a pattern, strategy as a position (positions), strategy as a tactic (ploy) and finally strategy as a perspective.

a. Understanding strategy as a plan is a program or planned step (a directed course of action) to achieve a set of predetermined goals or ideals; as well as the concept of strategic planning.

b. Understanding strategy as a pattern (pattern) is a consistent pattern of past behavior, using a strategy that is awareness rather than using a planned or intended one. What is a different pattern with intention or meaning, strategy as a pattern refers more to something that just appears (emergent).

c. The definition of strategy as a position is to determine the brand, product or company in the market, based on the conceptual framework of consumers or policy makers; a strategy is primarily determined by external factors.

d. Understanding strategy as a tactic, is a specific maneuver to trick or outwit the opponent (competitor).

e. Understanding strategy as a perspective is executing strategies based on existing theories or using natural instincts from the head or way of thinking or ideologically. 
f. In management practice, strategy is often used which is usually referred to as strategic management or strategic planning.

Tourism

Tourism comes from two words, namely from the word "pari" which means around or a lot, while tourism has the meaning of going. According to the Big Indonesian Dictionary, tourism is an activity related to recreational travel. While the general understanding of tourism is a trip that is carried out by someone for a while which is carried out from one place to another by leaving the original place and with a plan or not the intention of making a living in the place he visited, but solely to enjoy recreational or recreational activities to fulfill desires. diverse.

Tourism is a whole related elements which consist of tourists, tourist destinations, travel, industry and so on which are tourism activities. Tourism is the main source of foreign exchange because Indonesia is one of the countries that has various types of tourism, such as natural, social and cultural tourism which spread from Sabang to Merauke. In addition to storing millions of natural tourist charms that are so beautiful, Indonesia is also rich in cultural tourism as evidenced by so many historical relics and the diversity of arts and cultural customs of the local community that attracts local and foreign tourists, so that with the many potentials it has, it makes Indonesia as a place to be. a tourist destination. (Helln Angga Devy, R. B Soemanto; 2017)

The United Nations World Tourism Organization (UNWTO) recognizes that the tourism sector is a leading sector (tourism is a leading sector) and is one of the important keys for regional development in a country and improving welfare for the community.

\section{Alternative Tourism}

Alternative tourism is another option, another possibility or another way of traveling. Alternative tourism became known and became an option in tourism in the 84's which emerged to respond to increasing human interest and knowledge about tourist travel. Alternative tourism is also a response to public concern for environmental balance, preservation of natural and cultural resources, as well as public interest in outdoor tourism activities.

Alternative tourism is tourism that strongly emphasizes the importance of balance and sustainability of the quality of natural resources, the environment, culture and the community that owns the tourism assets. Therefore, in developing an alternative tourism object, the involvement of the local community as the owner of the tourist area gets a place. the main thing, starting from planning implementation as well as monitoring and utilizing the benefits obtained.

Meanwhile, according to Suwantoro (2001: 75) the term Alternative Tourism has two meanings, namely as follows: a) as a form of tourism that arises as a reaction to the negative impacts of conventional tourism development and development; b) as a different form of tourism (which is an alternative) from conventional tourism to support environmental sustainability.

Concerns that arise in various circles, such as intellectuals, clergy, environmentalists, community leaders, and others, about the negative impacts that occur as a result of tourism activities, encourage them to try to find a way out of these problems. They assume that, tourism requires a good environment, and also that tourism can be used as an instrument in supporting environmental, social, and cultural preservation of the local community that owns the tourist attraction.

\section{Agrotourism}

Yoeti (1999:144) states that Agrotourism is a translation of the English term Agro Tourism. Agro means agriculture and tourism means tourism/tourism. Agrotourism or agrotourism is travel to agricultural areas. Agriculture in a broad sense includes smallholder agriculture, plantations, forestry, animal husbandry, and fisheries. Agrotourism is 
not only seen from the results, but is related more broadly to the ecosystem, even the environment in general.

Agrotourism or agricultural tourism is a type of tourism that is relatively new to Indonesia, which has only been around since the late 1980s (Kompas, Dec: 2000). In simple terms, agro-tourism is in the form of recreation on agricultural land, both for food crops and horticulture, plantations, forestry, fisheries, or animal husbandry.

Looking at the description of agro-tourism as mentioned above, it can be concluded that this type of agro-tourism generally takes place or is located in rural areas.

\section{Sustainable Development}

In the development of alternative tourism, the concept of sustainable development is an alternative concept that includes efforts to maintain ecological integrity and diversification, meet basic human needs, open options for future generations, reduce injustice and increase self-determination for local communities.

The cultural environment is now experiencing very heavy pressure, as is experienced by the natural environment. Human cultural heritage is now in a position that is quite dangerous and alarming, and all the pressures experienced are not solely caused by the rapid development of the tourism industry, but also due to various factors such as urbanization, the rapid increase in world population growth, the entry of industrial technology that is out of control (uncontrolled), but because of the rapid changes in infrastructure that occur in many countries in the world.

Facing this reality, like it or not, scholars, environmentalists, community leaders, clergy and others, try to provide solutions or solutions that can prevent or minimize the negative impacts of development that have taken place so far, development that does not pay attention to all the heritage of natural resources and human culture, which is only concerned with economic growth alone. For this reason, a different approach is used, namely an approach that emphasizes the importance of art! existence and sustainability of natural resources, the environment and human culture for the lives of future generations. Therefore, the sustainable development approach, aims to stop disintegration, seek and provide as many cultural choices as possible for future generations.

According to Grundy (1993) the concept of $\mathrm{SD}$ is 'a new set of values, beliefs and assumptions'. For Grundy, the emerging paradigm sees humanitarian issues and the natural environment not as two separate things. As a result, SD can improve social status and still ensure sustainability for future generations.

Specifically, Grundy stated that the concept of SD consists of 3 (three) system elements which are related to: 1) ecological sustainability; 2) social sustainability; 3) economic sustainability.

This is also in accordance with the report of the World Commission on Environment and Development (WCED, 1987) which states that: "Sustainable Development is Development that meets the needs of the present without compromising that ability of the future generation to meet their own needs". Likewise, the WTO (1993), puts forward the principles of sustainable development which include: 1) ecological sustainability; 2) social and cultural sustainability; and 3) economic sustainability, both for current and future generations.

The rise of discourse on sustainable development also touches the field of tourism. Sustainable tourism development is defined as a tourism development process that is oriented towards the sustainability of the resources needed for development in the future. The emphasis of sustainable tourism development is not only on ecology and economy, but also on cultural sustainability because culture is also an important resource in tourism development (Wall, 1993).

Strategic Plan of the Tourism Office

Suparmi (2003) in his thesis entitled 'Human Resource Development Strategy to 
Support Evening Agrotourism (Case Study in Belok Sidan Village, Petang District, Badung Regency)' said in his research that the development of agro-tourism that relies on natural potential alone would be meaningless if not supported by HR. Because the success of a program is highly dependent on its implementers. The implementers are humans. For this reason, human resources need to be handled appropriately according to their abilities and wishes. If not handled properly then it will be the main destroyer.

Sudiasa (2005) in his thesis entitled 'Agritourism Development Strategy in Pancasari Village, Sukasada District, Buleleng Regency' stated in his research on agro-tourism development that agro-tourism development must be in accordance with the mission and vision of the development of the area itself. Must refer to the development of agro-tourism by utilizing the customs and culture of the community so that the results of agro-tourism can be enjoyed by the community in general.

Previous research, both in the form of Thesis and Thesis which took place in Agrotourism in Kebon Agung Village, did not exist and this research is the first research and thesis study that raises the topic and material about Agrotourism in Kebon Agung Village. The similarity of this research to previous research only lies in the similarity of research that both examines agro-tourism in general and in general, while the difference is that this research focuses more on examining the profile of agro-tourism in Kebon Agung Village, agrotourism development strategies in Kebon Agung Village and agro-tourism development programs in Kebon Agung Village. X.

\section{Framework for Thinking}

The strategic planning process according to Backler (1996:2) consists of several steps, namely: defining the mission and vision, setting goals, analyzing the external environment, analyzing the internal environment, developing strategies, developing program plans, implementing programs and making recommendations as the final result.

The vision and mission of development and development of East Java tourism is translated into the vision and mission of developing Kebon Agung tourism, namely cultural tourism with a populist feel. This means that the development of Kebon Agung tourism utilizes the customs and culture of Kebon Agung in general as a tourist attraction and avoids development that is conglomerate or accentuates its populist nature, so that tourism results will be enjoyed by the general public. One of the descriptions of cultural tourism with populist nuances is the development of agrotourism (Agricultural Tourism).

Kebon Agung Temu can be considered as an area or if in the business world it can be considered as a company whose potential will be developed into reality so that an agritourism profile is obtained. For this purpose, a typological approach is used, one of the four most appropriate and suitable approaches to obtain a profile or general description of agrotourism. The typological approach requires five criteria, namely tourist attractions, distance traveled, village size, belief and community systems, and the availability of infrastructure. The explanation of each of these criteria is only obtained through empirical studies, both through interviews with community leaders and the general public as well as direct observations at the study site.

Like an area, of course it has an environment that can be separated into the inner environment of the region called the internal environment and the outer environment of the region called the external environment. Referring to strategic management textbooks, the internal environment consists of strengths and weaknesses and the external environment consists of opportunities and threats. on the external environment if identified consists of factors. Furthermore, with the help of a SWOT analysis tool, a combination of internal and external factors can be made in the form of a 
SWOT analysis, the next one from this matrix is Kebon Agung

Back to referring to Backler's (1996:2) thinking, where from the general strategy (Grand Strategy) programs can be formulated, so even this study will formulate programs which are the operationalization of each general strategy. Finally, from the general strategy or development program, recommendations can be made to the authorized or competent agencies in the tourism sector in Tabanan Regency or in Bali Province, which in the future if conditions and circumstances allow it can be implemented into an action program

\section{METHODE}

\section{Research design}

Evaluation of the Implementation of the Alternative Tourism Strategy of Kebon Agung as the Embodiment of the Implementation of the Strategic Plan of the East Java Province Tourism Office 2016-2021 using a qualitative approach. Bogdan and Taylor (1975:5) define qualitative research as a research procedure that produces descriptive data in the form of written or spoken words from people and observable behavior. According to Lexy J. Moleong (in Prastowo, 2010:23) qualitative research is research whose research results must be confirmed to the research subject in order to build an accurate understanding of the subject itself. Based on this explanation, This type of qualitative research requires accuracy in obtaining and processing data which ultimately requires confirmation directly by the research subject and acknowledged as true. According to Kriyantono (2006:58) qualitative research does not prioritize the size of the population or sample. The thing that is prioritized in this research is the quality of the data.

The type of research that will be carried out by the researcher is descriptive qualitative research. Qualitative descriptive research aims to describe everything that is currently in effect. In it there is an attempt to describe, record, analyze and interpret the conditions that are currently happening or exist. In short, descriptive qualitative research aims to obtain information about the existing situation (Mardalis 1999:26).

The preparation of agro-tourism design in Kebon Agung uses a Typological Approach. The typological approach is based on the dissimilarity or difference in the characteristics of each area that will be developed for agrotourism, so that it will cause different colors or patterns of agro-tourism in the area. The difference in the characteristics of an area usually lies in the nature of the existing attractions and the distance from a tourist area, in this case more in the resort area (lodging). Based on the two factors above, namely attractions and mileage as a consideration, it will affect the packaging of the form of tour packages, so that tourists visiting the village will have several choices, including:

a. Stop for a moment (stop for a moment/stop over)

In this model, the attractions that exist in an area are single and less varied, so that tourists can only enjoy these attractions for a while. In this model, tourists and the community interact very minimally even without direct interaction, so that the benefits obtained by the community are also relatively small (Anonymous 1999).

b. Pause for a while (rest for a -while)

In this model, the attractions in an area vary quite a bit, so that it inspires tourists to stop for a while. For example, a day trip (one day trip) to the location of the visit by eating with residents, doing activities together with residents then tourists return to the hotel. In this model In this case, tourists only stop for a while without having to stay at the location. The benefits obtained by the community are slightly more than the first model (Anonymous 1999).

c. Stay (overnight stay)

In this model, tourists are moved to want to stay or spend the night at the location of the visit. Various considerations related to the impact, carrying capacity of the area and 
the potential of the local community, require coaching, training and development. Because in this model tourists stay longer than previous models, then the local community will benefit more if the area is managed with proper management (Anonymous 1999).

Some of the criteria needed in this approach include: tourist attractions, distance traveled, village size/characteristics, belief and community systems, and availability of infrastructure, each of which can be explained as follows:

a. Tourist Attractions

The tourist attractions referred to here are all that include nature, culture and manmade creations. The selected and developed attractions are the most attractive and attractive attractions in the village. For example, natural attractions can be in the form of natural scenery, including valleys. , mountains and rivers. For cultural attractions, it can be in the form of a way of life, while for human creations it can be in the form of monuments or traditional buildings.

b. Mileage

The distance traveled here is the distance from where the tourists stay and also the distance from the provincial capital and the distance from the district capital.

c. Village Size/Characteristics

The size of the village concerns issues related to the number of existing houses, the number of residents and their characteristics as well as the area of the village. This is important to be used as a criterion related to the carrying capacity of tourism in a city.

d. Belief System and Society

The belief system needs to be used as a criterion, given the existence of special rules or norms in a village community. What needs to be considered for this criterion is what religion the majority of the village population is and what is the existing social-society system. For example, the community is obedient and strongly adheres to certain norms or the community is more open to accepting updates from outside the village.

e. Availability of infrastructure

Availability of infrastructure includes: transportation facilities and services, electricity facilities, clean water facilities, dTahiase, telephone and sometimes radio communication, especially for remote areas or mountainous areas. The availability of infrastructure is very supportive in determining the type of development that is suitable for a village or an area.

Each of the above criteria is used to see and analyze the main characteristics of a village and then determine whether a village will become a village with a pause type, stop for a while or a stay type village.

Research Object and Research Time; The research location is a smallholder plantation area (coffee, fruit, etc.) as one of the seven agro-tourism areas that have the potential to be developed. it is not wrong if the potential for agro-tourism here needs to be inventoried, so that its profile can be seen and then a strategy and development program are formulated.

Sample and Sampling Technique:This research uses purposive sampling technique. The sample is selected based on certain considerations. In purposive sampling, researchers tend to choose informants who are considered to know and can be trusted as sources of solid data to know the problems studied in depth (Sutopo, 1998: 22). The informants came from the internal of the East Java Provincial Tourism Office which consisted of the marketing department and supporting informants who were considered to have mastered tourism in Kebon Agung Village, Ujung Pangkah District, Gresik.

Types of Research Data, Data collection was carried out using three methods, namely interviews, observation and documentation

Data Sources and Types, There are two kinds of data sources, namely primary data sources and secondary data sources. Primary 
data sources are data sources from the first hand or directly collected from first sources, such as village officials, government officials and community leaders in Kebon Agung Village. While secondary data sources are sources of data from second hands or those that have been collected by other people or agencies, such as data regarding village potentials sourced from village monographs, district and provincial tourism agency reports and data from the East Java Provincial Statistics Office and its specifics. There are two types of data collected, namely quantitative data and qualitative data. Quantitative data is data in the form of quantity or numeric or numbers, namely: area, distance traveled, population, etc. While qualitative data is tangible data, not numbers or numeric, but verbal information, namely:

a. The uniqueness of the area compared to other areas

b. The uniqueness and traditions of farmers and/or local communities

c. The uniqueness of plants and animals

d. The uniqueness of cultural attractions, especially agricultural culture

e. Local specialties

f. Local arts

g. Types of supporting institutions, such as subak abian, existing (sekehe) groups

h. Public perception of agro-tourism development plans

i. Infrastructure support

Research Respondents

The study respondents (people who gave answers to the questions asked) were government officials, officials and banjars, such as the Village Head, Heads of Affairs (Kaur), Kelian Desa/Bajar Adat and competent community leaders in Tabanan Regency. The method used to obtain data from respondents is by purposive sampling. Because the selection of the names of the respondents above has represented the aspirations of the residents of Kebon Agung village as a whole. From these respondents, it is hoped that data and information, both quantitative and qualitative, will be obtained regarding the hidden agrotourism potential here. From the data and information obtained, it is then processed and analyzed in order to obtain a profile and then formulated strategies and development programs as an agro-tourism area.

\section{Data Collection Method}

Data collection in this study used 1 data collection method with 2 data collection techniques, including:

a. Observation method, namely direct observation to the field or to the area using an observation guide instrument. This method complements the interview method or in other words validates the interview method, so that the data and information obtained are valid and accurate.

b. Interview technique, namely primary data collection, mainly qualitative data types through interviews with respondents using an interview guide instrument (Guide Interview).

c. Participatory Techniques, which is a method by involving the community or community leaders in formulating agrotourism development programs in area $\mathrm{X}$

\section{Data Analysis Method}

Data analysis methods used in this study include:

a. Qualitative Method; The qualitative method is to provide a review or interpretation or to the data and information obtained, so that it becomes more meaningful than just a presentation in the form of numbers (numeric). This method is used on the results of the analysis of the Typological Approach to the potential and profile of agro-tourism and the results of internalexternal analysis and the results of the SWOT analysis.

b. Strategic Plan Method; This method is taken from the adaptation of the Strategic Planning Process according to (Backler, 1996:2). As for what will be discussed in this method is the analysis of the Internal- 
External Situation then followed by a SWOT Analysis. From the combination of the two results of the analysis, a Development Strategy Formulation will be produced. From the Development Strategy, a Development Program can be formulated which is the Operationalization of the Development Strategy. The formulation of the Development Program will be divided into two. Namely, the Short-Term Program and the Long-Term Program which will eventually be implemented into an Action Program in the development of Agrotourism.

c. Internal-External Situation Analysis; Analysis of the internal-external situation is intended to identify the internal situation in the form of factors that become strengths and weaknesses and factors that become opportunities and threats for agro-tourism development

The identification of this situation is the information base for a SWOT analysis, with the following stages:

1) List the external opportunities of agrotourism areas

2) Make a list of external threats to agrotourism areas

3) List the internal strengths of agrotourism areas

4) Make a list of the internal weaknesses of the agro-tourism area

d. SWOT Analysis

SWOT analysis is a continuation of the Internal-External situation analysis, where internal factors in the form of strength and weakness factors are combined with external factors in the form of opportunity and threat factors, where this combination will produce several general strategies (Grand Strategy) development agrotourism in Kebon Agung

Referring to Umar's opinion (2001), there are eight stages in formulating a strategy for developing agro-tourism areas in Kebon Agung Village through a SWOT analysis, as follows:
1) Place the strength and weakness factors in columns 2 and 3, the opportunity and threat factors in rows 2 and 3 respectively in the SWOT analysis (Table 1).

2) Formulate an SO strategy which is a combination of the strength and opportunity factors placed in the SO strategy set.

3) Formulate a WO strategy which is a combination of opportunity weakness factors that are placed in the WO strategy cell.

4) Formulate the ST strategy which is a combination of threat strength factors placed in the ST strategy cell.

5) Formulate a WT strategy which is a combination of threat weakness factors placed in the WT strategy cell.

Table 1: SWOT Analysis

\begin{tabular}{|c|c|c|}
\hline $\begin{array}{l}\text { Snternal } \\
\text { Situation } \\
\text { External } \\
\text { Situation }\end{array}$ & $\begin{array}{l}\text { STRENGTH }(S) \\
\text { Identify } \\
\text { Weakness } \\
\text { Factors }\end{array}$ & $\begin{array}{l}\text { WEAKNESS( } \\
W) \\
\text { Identify the } \\
\text { Strength } \\
\text { factors }\end{array}$ \\
\hline $\begin{array}{l}\text { OPPORTUNI } \\
\text { TY }(O) \\
\text { Identify } \\
\text { opportunity } \\
\text { factors }\end{array}$ & $\begin{array}{l}\text { SO } \\
\text { STRATEGY } \\
\text { Create a } \\
\text { strategy that } \\
\text { Using power } \\
\text { To take } \\
\text { advantage of } \\
\text { Opportunity }\end{array}$ & $\begin{array}{l}\text { WO } \\
\text { STRATEGY } \\
\text { Create a } \\
\text { strategy that } \\
\text { Minimize } \\
\text { weakness for } \\
\text { take advantage of } \\
\text { opportunities }\end{array}$ \\
\hline $\begin{array}{l}\text { THREAT }(T) \\
\text { Identification } \\
\text { of factors- } \\
\text { Threat factor }\end{array}$ & $\begin{array}{l}\text { STRATEGIST } \\
\text { Create a } \\
\text { strategy that } \\
\text { Using force to } \\
\text { deal with threats }\end{array}$ & $\begin{array}{l}\text { WT } \\
\text { STRATEGY } \\
\text { Create a } \\
\text { strategy that } \\
\text { Minimize } \\
\text { weakness and } \\
\text { avoid threats }\end{array}$ \\
\hline
\end{tabular}

(Adapted from Rangkuti, 2001)

Information :

1) SO (Strength - Opportunity) strategy, using the strengths you have to take the opportunities that exist;

2) ST strategy (Strength - Threat), using strength to avoid and overcome threats; 
3) WO (Weakness - Opportunity) strategy, using the opportunities they have to overcome weaknesses;

4) WT (Weakness - Threat) strategy seeks to minimize weaknesses and avoid threats.

e. Development Program Analysis; The strategy can be said to be still in the form of general steps that are very floating and the direction is not clear. Therefore, in accordance with the hierarchy of strategic planning processes, strategy formulation should be followed by a concrete plan called a program, which later if a budget is available it can be realized into an action program or project. The formulation of the Development Program can only be obtained if the internal-external analysis factor data has been obtained in the field, and the results are processed using a SWOT analysis. Based on the combination of the obtained strength-weakness and opportunity-threat factors, By using the interpretive method, the development strategy can be formulated. From the development strategy, the Development Program which is the operationalization of the development strategy can be formulated. The formulation of the Development Program will be divided into two. Namely, Short-Term Programs and Long-Term Programs. The data obtained to formulate the Short-Term and Long-Term Programs are adjusted to the results of the data obtained in the field.

\section{RESULTS AND DISCUSSION}

Village Condition Village History

Kebonagung Village is one of the villages included in the Ujungpangkah sub-district, Gresik Regency which was formerly located east of the highway. Previously, Kebonagung Village consisted of 3 small hamlets named Bondalem, Murtowo, Bonsari which were only inhabited by a few dozen families. Because in the early 50s there was an outbreak of infectious diseases so that many people died.
According to the history told by village elders at that time, in 1950 the 3 hamlets were moved to the west, then changed its name to Kebonagung Village until now.

The condition of the population at that time was very worrying because of the lack of health care, as well as the number of disease outbreaks, the people never reaped the harvest because of the large number of wild boars and monkeys eating their crops. Coupled with the management system that is still traditional by relying on the weather.

Efforts have been made to control disease outbreaks, such as hiring a team of wild boar and monkey hunters and working together to eradicate monkeys and pigs. Since then, Kebonagung Village has become a village that has moved from adversity and over time, Kebonagung Village has become a fertile and prosperous village.

Vision and Mission of Kebonagung Village

a. "The Realization of a Fair and Prosperous Kebonagung Village, Safe, Healthy, Intelligent, Independent, Cultured and Has Noble Morals"

b. This vision is a goal that the people of Kebonagung Village want and want to achieve in the future.

c. Mission

d. "Building with the Community and Creating a Characterized, Independent and Cultured Kebonagung Village"

e. The mission is the steps he will take in order to realize the success of the mission that has been set.

f. Motto of Kebonagung Village "Unpretentious Botanical Gardens"

Demographics

Based on the 2020 Kebonagung Village Government Administration Data, the population of Kebonagung Village consists of 329 houses, 423 families, a total population of 1399 people with details of 717 male residents and 682 female residents.

Education

Education is an important thing in advancing the level of HR (Human Resources) 
which can affect the improvement of the economy in the long term.

Higher levels of education will increase the level of community skills and will be able to encourage the growth of new skills and entrepreneurship, so that new job opportunities will be formed, and of course this can be in line with government programs in reducing unemployment and poverty in the community.

Table 2: Education Data

\begin{tabular}{|l|l|l|l|}
\hline No & $\begin{array}{l}\text { Education } \\
\text { Name }\end{array}$ & $\begin{array}{l}\text { Number } \\
\text { of units })\end{array}$ & Note. \\
\hline 1 & PAUD & 2 & \\
\hline 2 & kindergarten & 2 & \\
\hline 3 & SD/MI & 2 & \\
\hline
\end{tabular}

Community Education Data

\begin{tabular}{|l|l|l|l|}
\hline No & Information & amount & Note. \\
\hline 1 & No/Not yet School & 158 & \\
\hline 2 & $\begin{array}{l}\text { Not Finished } \\
\text { Elementary School }\end{array}$ & 135 & \\
\hline 3 & Elementary School & 343 & \\
\hline 4 & $\begin{array}{l}\text { Graduated from } \\
\text { Junior High } \\
\text { School/Equivalent }\end{array}$ & 275 & \\
\hline 5 & $\begin{array}{l}\text { High school } \\
\text { graduate/equivalent }\end{array}$ & 409 & \\
\hline 6 & Graduated Diploma & 31 & \\
\hline 7 & Graduated S1/S2 & 68 & \\
\hline
\end{tabular}

Health

Health services are the right of every community and are very important for improving the quality of society in the future. One of the health service facilities in the village is the availability of public health services. The number of public health service places in Kebonagung Village are as follows:

Table 3: Health Data

\begin{tabular}{|l|l|l|}
\hline No & Name & Address \\
\hline 1 & $\begin{array}{l}\text { Ponkesdes } \\
\text { Kebonagung } \\
\text { Village }\end{array}$ & $\begin{array}{l}\text { RT 001 RW } \\
003 \\
\text { Kebonagung } \\
\text { Village }\end{array}$ \\
\hline 2 & Integrated & $\begin{array}{l}\text { RT 001 RW } \\
001 \\
\end{array}$ \\
& Healthcare \\
& Center \\
& Kebonagung \\
& Hamlet & Village \\
\hline
\end{tabular}

\begin{tabular}{|l|l|lr|}
\hline 3 & Integrated & Dsn Kowang \\
& Healthcare & RT 002 RW \\
& Center & 001 & \\
& Kowang & & \\
& Village & & \\
\hline
\end{tabular}

\section{Social Condition}

Political dynamics and various changes to a more democratic political system have an influence on people who apply a political mechanism that is considered more democratic.

In the scope of local politics, Kebonagung village is reflected in the election of village heads and other elections such as legislative elections, presidential elections, gubernatorial elections, regent elections that involve the village community directly.

The deliberation held in Kebonagung Village involves the community directly. For example, in the implementation of Musrenbang, the leadership remains in the hands of the village head. However, decision making is determined in a joint decision between the Village Head and the Village Consultative Body (BPD). Thus, it can be seen that the leadership pattern in Kebonagung Village prioritizes a democratic leadership pattern.

In terms of religion, the people of Kebonagung Village still use Javanese cultural and social aspects. This is illustrated by the use of the Javanese calendar and the Islamic calendar, for example in carrying out Thanksgiving activities.

Likewise in Islamic commemoration activities, the community is always enthusiastic in carrying out these activities.

Economic Condition

The livelihoods of the people of Kebonagung Village are listed in the following sectors:

Table 4: Economic Condition

\begin{tabular}{|l|l|l|l|}
\hline No & Livelihood & amount & Note: \\
\hline 1 & $\begin{array}{l}\text { Not yet/Not } \\
\text { working }\end{array}$ & 265 & \\
\hline 2 & $\begin{array}{l}\text { Taking care of } \\
\text { household }\end{array}$ & 200 & \\
\hline
\end{tabular}




\begin{tabular}{|l|l|l|l|}
\hline 3 & Student/Student & 249 & \\
\hline 4 & $\begin{array}{l}\text { TNI/Police/PNS } \\
\text { /Retirees }\end{array}$ & 11 & \\
\hline 5 & Employees & 31 & \\
\hline 6 & $\begin{array}{l}\text { Farmers/Growe } \\
\text { rs }\end{array}$ & 341 & \\
\hline 7 & Fisherman & 1 & \\
\hline 8 & Freelance & 58 & \\
\hline 9 & $\begin{array}{l}\text { Teacher/Lecture } \\
\text { r }\end{array}$ & 23 & \\
\hline 10 & $\begin{array}{l}\text { Doctor/Midwife } \\
\text { /Nurse }\end{array}$ & 2 & \\
\hline 11 & Merchants & 5 & \\
\hline 12 & entrepreneur & 112 & \\
\hline 13 & Others & 101 & \\
\hline
\end{tabular}

Village Government Conditions

The Kebonagung Village area is located on a plain area of $156 \mathrm{Mdl}$ with the following coordinates:
a. Longitude Coordinates
$: 112.532711$
b. Latitude Coordinates
: -6.939269

The regional boundaries are as follows:
a. aNorth : Pangkahkulon and Pangkahwetan villages
b. East : Karangrejo Village and Ketapang Village
c. South side : Bolo Desa Village
d. West Side : Gosari Village

The Kebonagung Village Government is centered on the Kebonagung Village Office which is located at RT 002 RW 003 and occupies an area of 2,411 m2.

The Kebonagung Village area is divided into 2 areas, namely:

a. The Kebonagung Hamlet area, which consists of 3 Neighborhood Units (RT) and 1 Residents Association (RW)

b. Kowang Hamlet area, which consists of 8 Neighborhood Associations (RT) and 3 Residents' Associations (RW)

\section{CONCLUSION}

There is only one analytical technique at the decision stage in strategy formulation to determine the relative attractiveness and appropriate alternative actions. The technique is the Quantitive Strategic Planning Matrix (QSPM) which forms stage 3 of the formulation strategy. QSPM is a tool that enables strategists to evaluate internal key factors. Conceptually, the QSPM determines the relative attractiveness of various strategies from the extent to which key internal and external success factors are utilized or enhanced. This research begins by analyzing the Kebon Agung village, Ujung Pangkah sub-district and the SME development plan, followed by implementing the next model, the implementation of the strategy model can be reconstructed according to the conditions of development. There is only one analytical technique at the decision stage in strategy formulation to determine the relative attractiveness and appropriate alternative actions. The technique is the Quantitive Strategic Planning Matrix (QSPM) which forms stage 3 of the formulation strategy. QSPM is a tool that enables strategists to evaluate key internal factors. Conceptually, QSPM determines the relative attractiveness of various strategies from the extent to which key internal and external success factors are utilized or enhanced. Related to HR strategy, HR development program for performance.

\section{REFERENCES}

Andre Gunder Frank. 1976.Sociology of Development and Under Development of Sociology. Pluto Press (Translation by Yiss) Pulsar library.

Bintarto, Tjokroamidjojo. 1982.Introduction to Thought on Theory and Strategy National Development Jakarta: Mount Agung.

Brian and White. 1987. Development Management. Jakarta: LP3ES Cemea, Michael. M. 1988. Prioritizing Humans in Development. Jakarta: Ul Press.

Chamber Robert 1983. Village Development. Jakarta: LP3ES AR design. 1983. Sociology An Introduction to Rural Restructuring in Village Rights and Integrity. Jakarta: Institute for Development Studies,

Eka Martinngsih Ngag, et al. 2009. Proposed Ib.W Program in Akah Village and other villages Bengkelsari, West Selemadeg, Tabanan, Bali, 2010/2012. LP2M Unmas Denpasar 